\title{
Indications and Methods of removing Dental Implants
}

\author{
${ }^{1}$ Dóra Iványi, ${ }^{2}$ Péter Kivovics
}

\section{ABSTRACT}

Aim: The aim of this research is to make a comparative interpretation of implant removals in the last $3 \frac{1}{2}$ years in the Department of Community Dentistry.

Materials and methods: In the last $3 \frac{1}{2}$ years, 27 patients' 46 implants were removed in the Department of Community Dentistry. The applied data were obtained by X-rays, medical charts, and patient management program, called FOGÁSZ, found in the Department of Community Dentistry. Data were evaluated with Microsoft Excel software.

Results: The average age was 63.7 years; $96.3 \%$ of the patients were aged 50 or over; $63.9 \%$ of the concerned individuals' inserted implants were removed. Among maxilla and mandible, there are equal proportions of removed implant's location partition; $22.7 \%$ of the patients lost their implants within 6 months from surgery. The removed implants were possessed 5.5 years long on average; $40.7 \%$ of the patients commanded fixed prosthesis-supported implant and teeth, and this was the most common prosthesis type. The prevalence of peri-implantitis around removed implants was $71.7 \%$. Out of the partly edentulous patients, horizontal bone resorption was discernible in $47.6 \% ; 15.2 \%$ of the removals were recommended because of inflammation before osseointegration.

Conclusion: Fixed prostheses anchored at the same time to tooth and implant may cause implant loss, because biomechanical aspects of anchoring behave differently in the bone. Lack of peri-implantitis is a key factor in the success of implants. Periodontitis could also promote the development of peri-implantitis.

Clinical significance: Avoid planning prostheses anchored at the same time to tooth and implant. Sufficient oral hygiene is essential for the prevention of inflammation. Patients with periodontitis should be cured of inflammation before implantation. Important factor for osseointegration is the inflammation-free healing.

Keywords: Endosseous dental implantation, Implant removal, Implants, Peri-implantitis, Research, Retrospective study.

How to cite this article: Iványi $D$, Kivovics $P$. Indications and Methods of removing Dental Implants. World J Dent 2018;9(3):180-186.

Source of support: This work was supported by the ÚNKP17-2 new national excellence program of the Ministry of Human Capacities.

Conflict of interest: None

1,2Department of Community Dentistry, Faculty of Dentistry Semmelweis University, Budapest, Hungary

Corresponding Author: Dóra Iványi, Department of Community Dentistry, Faculty of Dentistry, Semmelweis University, Budapest Hungary, Phone: +00363176600, e-mail: divanyi132@gmail. com

\section{INTRODUCTION}

Fifty years ago, implantation was only a complementary treatment for traditional dental prosthesis. Since then, implantation-supported restorations have become an everyday practice in dentistry. When the clinical and anatomical factors are appropriate, each types of edentulous patients are able to undergo prosthetic treatments. Several types of dental implants are developed and used in dentistry; however, this article will focus on endosseous root-form implants which are the most frequently applied in dentistry today. According to statistics, the success rate of implantation is high; nevertheless, there are still considerable implant failures that might require implant removals. The aim of this retrospective study is to aid practicing dentists by giving a comparative assessment of implant removals.

Literature shows that the success rate of implantation is within broad limits. According to certain authors, the survival proportion is about 90 to $99 \%{ }^{1-4}$ After implantation procedure, different complications can occur. Complications can be cured by nonsurgical or surgical therapy. In case the elected approach is ineffective, the implant should be removed. ${ }^{5,6}$ Indications of implant removal can be divided into two main groups: early and late indications. In the first case, the implant removal happens before the osseointegration, and when the implant removal happens after the osseointegration, we define it as late indication.?

\section{Early Indications}

Implant removals' early indications involve tissue injury caused by implant placement. Temporary or permanent sensory impairment may derive from injuries to nerve trunks during implant surgery. In the lower jaw, the inferior alveolar nerve injury might occur, provided the implant reaches the mandibular canal, or if it is collapsed. In these cases, the most common symptom is the torpidity of the mandible. Nerve trunk injuries may be treated medically or surgically depending on the extent of the pathological alterations and the neurological symptoms reported by the patient. ${ }^{8,9}$ Along with nerve trunk injuries, tooth near the implant could be damaged. Various therapies are available, tooth might be endodontically treated, extracted, or implant may be removed. ${ }^{10}$ In case of inadequate planning or procedure, the implant might be malpositioned, which may also effect implant removal., ${ }^{3,11}$ 
Appropriate imaging process, e.g., cone beam computed tomography, can aid the most ideal implant placement. Implant removal could be suggested if the primary stability is inadequate. Too hard primary stability induces bone resorption around the implant; however, implants' major amplitude micromovement caused by too low primary stability could inhibit osseointegration. ${ }^{12}$ Mention must be made of the inflammatory processes before the osseointegration. Excessive temperature generation during surgical drilling and inefficiently controlled wound healing could result in inflammation in the surrounding bone. ${ }^{13}$

\section{Late Indications}

Four main groups of late indications are considered next. Biological indication includes peri-implantitis. Peri-implantitis has been defined as a localized lesion involving bone loss around an osseointegrated implant. ${ }^{14}$ A study made in 2012 claims that the prevalence of periimplantitis has been reported to be in the order of $10 \%$ of implants and $20 \%$ of patients. ${ }^{15}$ Predisposing factors could be limited oral hygiene, smoking, systemic disease, poorly cleanable and overloaded prosthesis, history of peri-implantitis, soft tissue defects ,or poor-quality soft tissue at the area of implants. ${ }^{16}$ The treatment of periimplant infections comprises conservative (nonsurgical) and surgical approaches. Depending on the seriousness of peri-implant disease, implant removal might be required. ${ }^{17}$ Mechanical indications contain injury and fracture of the implant or the implants abutment. Most commonly, these conditions arise from implant overloading (Fig. 1). ${ }^{18}$ Neither mechanical indications are absolute indications of implant removal; alternative therapeutic methods exist along frequent radiographic control. ${ }^{19}$ Damaged implant might be kept in its place. Indications of implant removal concerning medical status are divided into several groups. Implant removal might be suggested

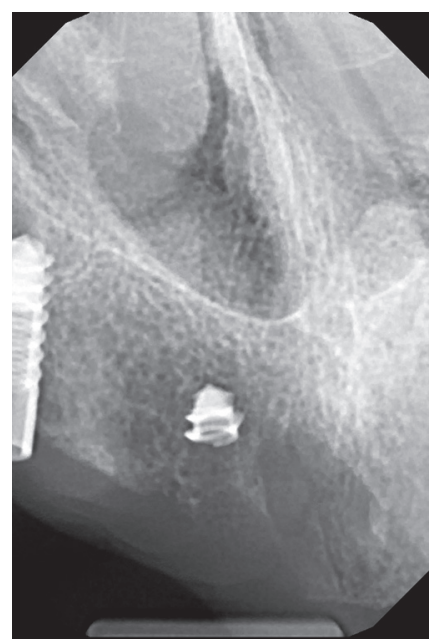

Fig. 1: Trauma caused by implant fracture after osseointegration surrounding maxillofacial tumors, according to the oncologic treatment. Implant removal might influence therapeutic success or decrease probability of side effects, e.g., osteonecrosis or serious inflammation. ${ }^{20,21}$ The removal may be recommended when the implant is considered to be a source of infection. The last class of late indications is physiological bone resorption. Bone resorption could be considered physiological if it is displayed up to 1.5 $\mathrm{mm}$ during the first year after placement and there are no inflammatory symptoms. It is called initial marginal bone resorption. ${ }^{22,23}$ Although bone resorption slows down afterward, eventually, it could lead to esthetic or stability problems that may recommend implant removal.

\section{Methods of Implant Removal}

Removing by torque wrench and screwdriver may be sufficient, supposing osseointegration is not accomplished. Simply we can twist the recently inserted implant out of its position. ${ }^{24}$ Removal can be done by dental forceps. This method demands more experienced surgeon, assuming that osseointegration is completed. For as much as the connection between the bone and the implant is ankylotic, exerting inadequate forces during removal might generate implant fracture or significant bone loss. ${ }^{25}$ Dental implants could be removed with conventional surgical drills or trephan drills (Fig. 2). These methods are applicable in osseointegrated cases, but their utilization in implant fracture during surgery might be avoided. ${ }^{26}$ Mention must be made that the aforesaid techniques result in significant bone loss and has financial implications (Fig. 3). Bone damage could be reduced by using piezoelectric surgical preparation. ${ }^{27}$ Special implant removal screws gain ground increasingly, because implant removal could take place without jeopardizing the surrounding bone or neighboring structures. The method is based on rupturing the connection between bone and implant, which is

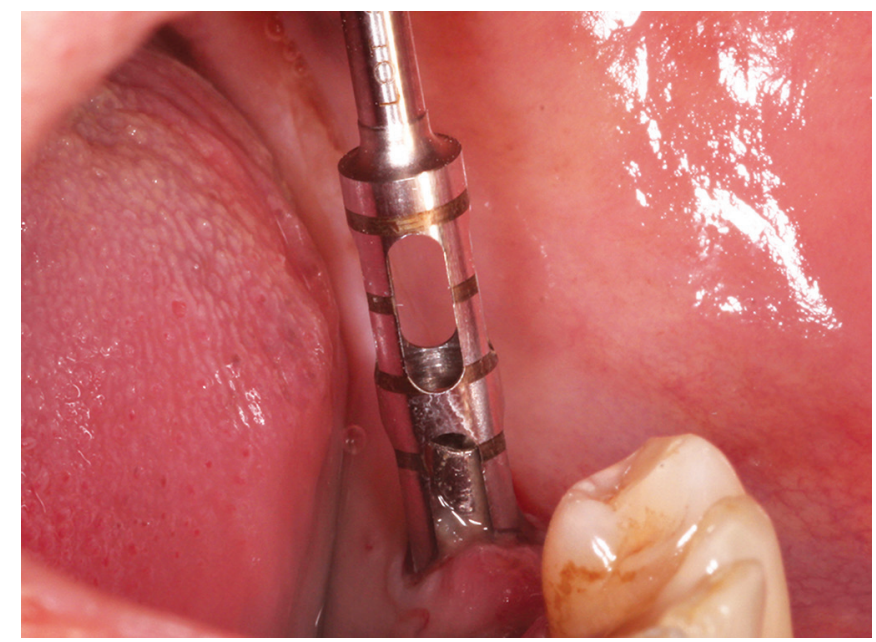

Fig. 2: Implant removal in mandible by trephan drill (from Dr Béla Czinkóczky's cases) 


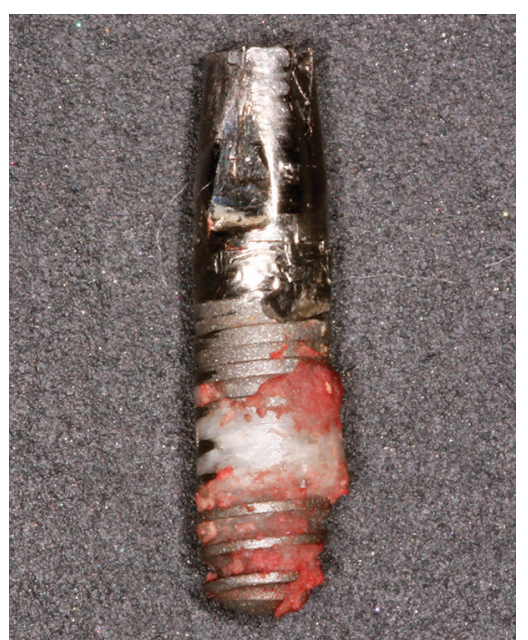

Fig. 3: Bone loss during trephan drill

reached by enough force in a counter clockwise direction. ${ }^{28}$ Of course, all procedures could be combined with each other, in favor of the most suitable result.

On account of the actuality of the present argument, the Department of Community Dentistry's workgroup proposed the investigation of implant removals. The aim of this research is to make a comparative interpretation of implant removals in the last $3 \frac{1}{2}$ years in the department. Our research implies the distribution of age and gender of the examined population, location of inserted and removed implant in the jaws, elapsed time between implantation and removal, the types of prostheses anchored by removed dental implants, and complications occurring with removed implants.

\section{MATERIALS AND METHODS}

In the last 31/2 years, 27 patients' (17 women and 10 men) 46 implants were removed in the Department of Community Dentistry; $84.1 \%$ of removed implants were not inserted in the department. The applied data were obtained by X-rays, medical charts, and patient management program, called FOGÁSZ, found in the Department of Community Dentistry. Data were evaluated with Microsoft Excel software.

\section{RESULTS}

\section{Age Distribution}

Average age of the examined population was 63.7 years (deviation is 9.0 years). Significant difference was not registered among women's and men's average age. Female's average age was 62.4 years (deviation is 5.6 years), whereas that of males was 66.0 years (deviation is 12.6 years); $96.3 \%$ of the patients were aged 50 or over; $29.6 \%$ were 51 to 60 years old, $51.9 \%$ were between 61 and 70 years, $14.7 \%$ were aged 71 to 80 ; and only $3.4 \%$ were in age group 31 to 40 .

\section{Implant Position in the Jaws}

An analysis of the inserted and removed implants locations within the jaws was made, considering laterality. Totally 72 implants were placed on patients who got through implant removal, on average 2.6 implants (deviation is 1.8) per participant. Inserted implants' percentage repartition on the left side: $8.3 \%$ were in the maxillary front region, $15.3 \%$ were in the maxillary premolar region, $4.2 \%$ were in the maxillary molar region, $8.3 \%$ were in the mandibular front region, 9.7\% were in the mandibular premolar region, and $8.3 \%$ were in the mandibular molar region. Inserted implants' percentage repartition on the right side: $6.9 \%$ were in the maxillary front region, $9.7 \%$ were in the maxillary premolar region, $2.8 \%$ were in the maxillary molar region, $9.7 \%$ were in the mandibular front region, $6.9 \%$ were in the mandibular premolar region, and $9.7 \%$ were in the mandibular molar region (Fig. 4A). About $63.9 \%$ of the concerned individuals' inserted implants were removed, counts 46 implants; 1.6 implants (deviation is 1.5) were removed per individual. From the removed implants, on the left side $8.7 \%$ were in the maxillary front region, $19.6 \%$ were in the maxillary premolar region, $2.2 \%$ were in the maxillary molar region, $4.3 \%$ were in the mandibular front region, $15.2 \%$ were in the mandibular premolar region, and $10.9 \%$ were in the mandibular molar region. On the right side, $10.9 \%$ of the removed implants were in the maxillary front region, $6.5 \%$ were in the maxillary premolar region, $2.2 \%$ were in the maxillary molar region, $8.7 \%$ were in the mandibular front region, $4.3 \%$ were in the mandibular premolar region, and $6.5 \%$ were in the mandibular molar region (Fig. 4B). Among maxilla and mandible, there are equal proportions of removed implant's location partition.

\section{Implant Survival Time}

Data about removed implant lifetime were available in 20 cases; $22.7 \%$ of the patients lost their implants within 6 months from surgery, earlier than the end of implant's osseointegration. Out of $22.7 \%, 9.1 \%$ had to be removed immediately after implantation; $9.1 \%$ of the examined population went through the explantation of the implants 1 st year, $4.5 \%$ in the $3 \mathrm{rd}, 4.5 \%$ in the $4 \mathrm{th}, 9.1 \%$ in the 6 th, $4.5 \%$ in the 7 th, $4.5 \%$ in the 9 th, $18.2 \%$ in the 10 th, $4.5 \%$ in the 11 th, and $4.5 \%$ after the 11th year (Graph 1). The removed implants were possessed 5.5 years (deviation is 4.4 years) long on average.

\section{Types of Prostheses anchored by removed Dental Implants}

This research extends to observe the distribution of the prostheses types anchored by removed implants; $40.7 \%$ of the patients commanded fixed prosthesis-supported 

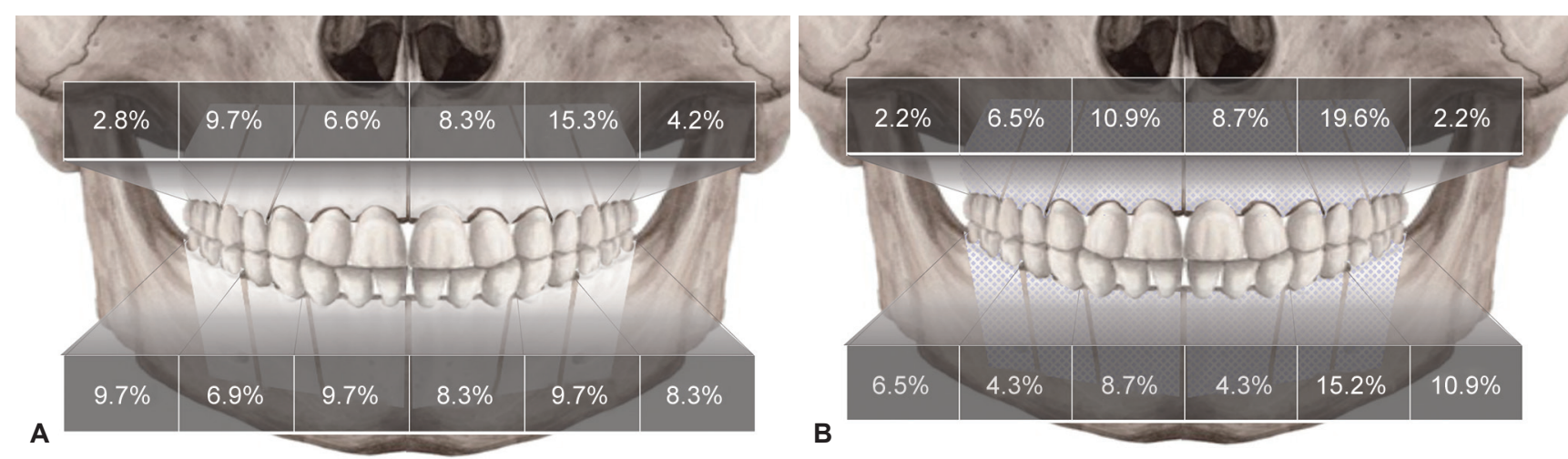

Figs 4A and B: (A) Inserted implants' percentage repartition in the jaws. (B) Removed implants' percentage repartition in the jaws

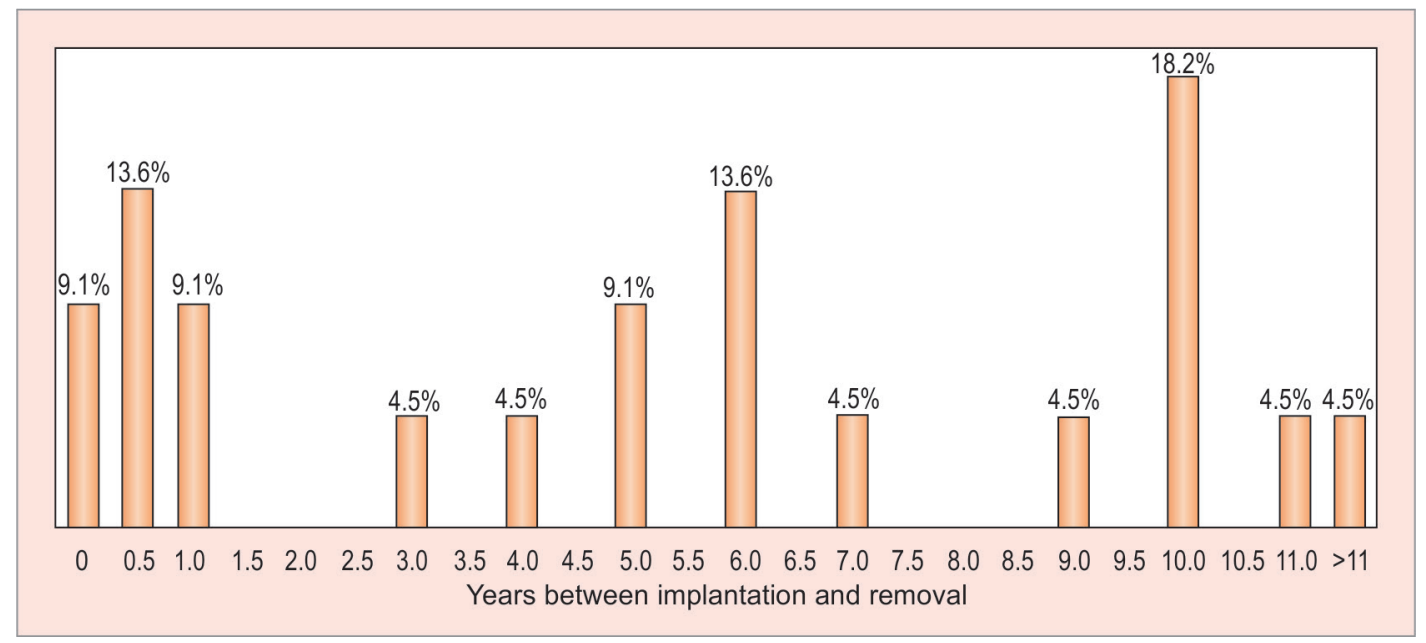

Graph 1: Implants' survival time

implant and teeth, $29.6 \%$ wore bridges anchored by dental implants, $18.5 \%$ wore full denture, and $11.1 \%$ wore dental crown (Graph 2).

\section{Complications concerning removed Implants}

The prevalence of peri-implantitis around removed implants was $71.7 \% ; 22.2 \%$ of the population was fully edentulous. Out of the remaining patients, horizontal bone resorption was discernible in $47.6 \%$, and over and above vertical bone defect was detectible in $14.3 \% ; 15.2 \%$ of the removals were recommended because of inflammation before osseointegration would have occurred. Only in two cases were found malpositioned implants; 2 of 46 removed implants were explanted through mechanical indications (Graph 3).

\section{DISCUSSION}

Over the age of 50, the prevalence of diabetes mellitus type II, cardiovascular diseases, and tumorous diseases is rising. ${ }^{29-31}$ Such morbidity weakens the resistance of the human body against bacteria and reduces the blood supply in different tissues, and thus, they might influ-

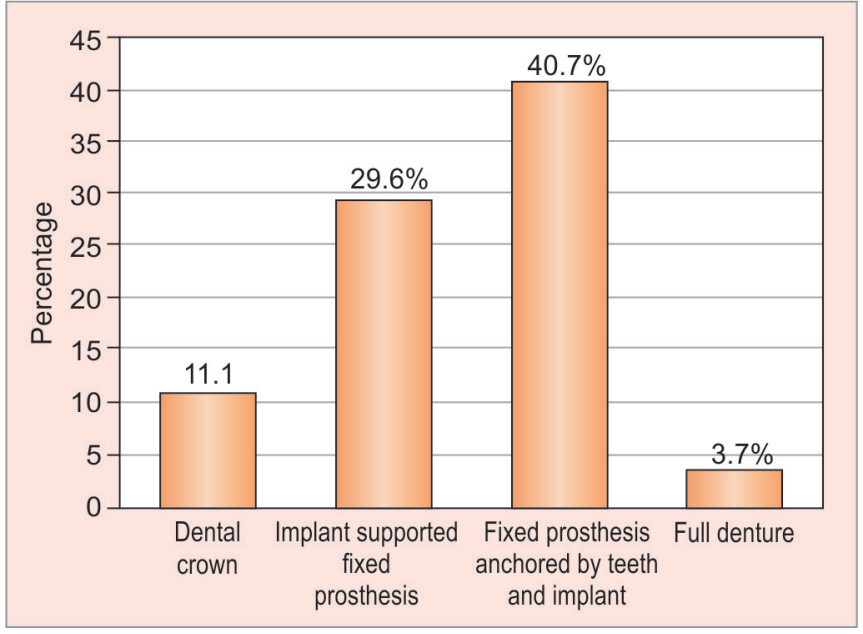

Graph 2: Distribution of the prostheses types anchored by removed implants

ence the undisturbed wound healing and the implant ossification. Accordingly, these common illnesses could be etiological factors in implant loss. According to a Hungarian study, the incidence of tooth loss is significantly growing over the age of $45 .^{32}$ In parallel, the incidence of tooth loss, the rate of prosthesis is also in a tendency 


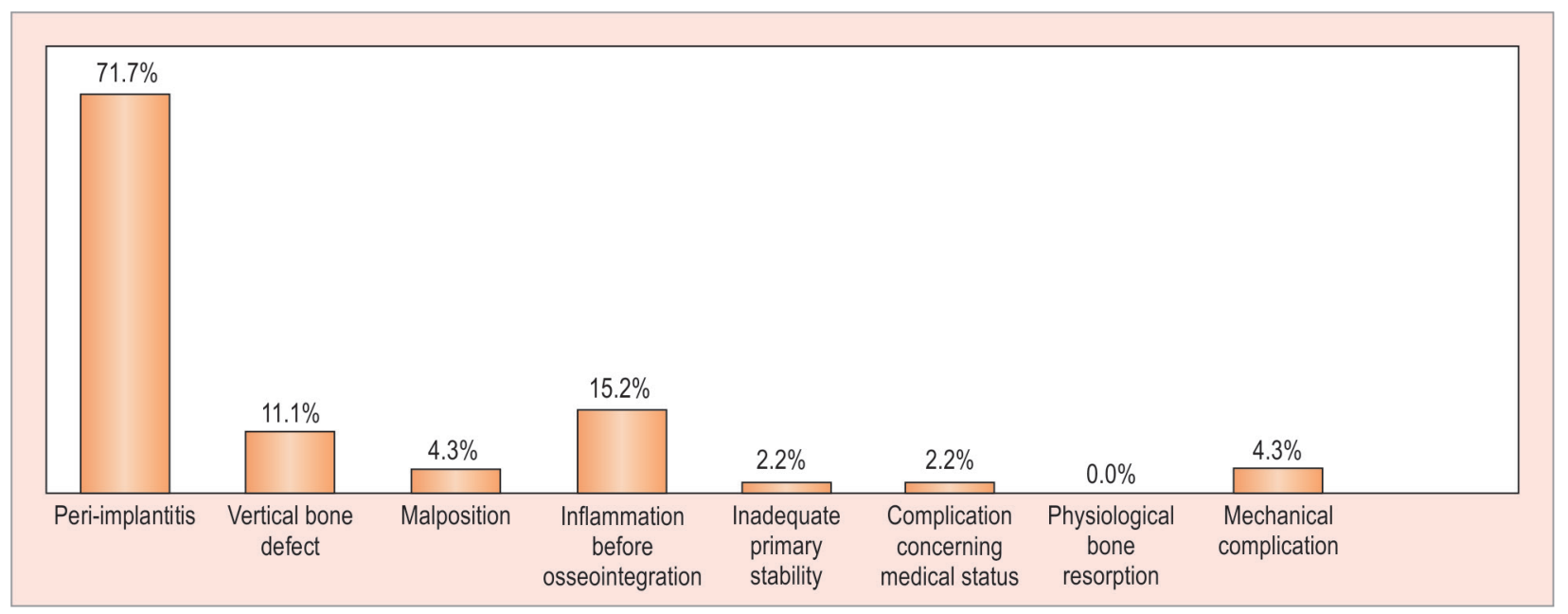

Graph 3: Complications concerning removed implants

to increase. ${ }^{33}$ The implantation-supported prostheses are gaining ground in everyday dental practice. We can conclude that with traditional dentures, the prevalence of dentures on implants is also increasing in the older age group. Consequently, inference might be deducted, that the frequent implantation in elder population may also heighten the implant removals over the age of 50. In our opinion, the $95 \%$ incidence of people over 50 in the examined population cannot be explained with only the higher prevalence of systematic diseases.

Observation can be made into the location of inserted and removed implants. Similarity can be established regarding the location of inserted and removed implants in identical regions, both in maxilla and in mandible. Notable difference is perceived between the left and the right side in maxillary premolar, in mandibular premolar and molar regions about removed implant's location. Further investigations and the number of cases need to be extended to determine the exact cause of the significant deviation measured in the different side regions. The fact that in the population there is a greater number of right-handers may cause a difference. Dissimilar simplified oral hygiene index (OHI-S) and decayed, missing, filled values were estimated in the right- and left-handed patients, which means that patients' laterality could influence the quality of oral hygiene and the extent of plaque accumulation around the implants. ${ }^{34}$ Removals in maxilla and in mandible were of equal proportions. It should be noted that in large-scale studies, the proportion of placement of inserted implants does not match with sudden results. ${ }^{1}$ Several studies have also investigated how structural differences between the two jaws affect the success of implantation. In our case, conclusion cannot be drawn that the blood supply and structural differences in the maxillary and mandible affect the survival of the implants. ${ }^{35,36}$ Further studies are needed to determine this inference.
Concerning the lifetime of removed implants, we can observe that there are three maxima in the time axis. The first spike is located in the first year of implantation. In these cases, implants were removed due to early indications. The second spike could be detected in 5 to 6 years. Among patients who belonged to this group, hard-to-clean prosthesis had been habitual, and except for a patient, everybody had a fixed denture with anchored teeth and implants. It is assumed that peri-implantitis due to inappropriate design and construction of the prosthesis has increased the number of more frequently happening implant removals. The last spike appears in the time axis around 10 years. In these cases, almost all types of prosthetics have occurred. The additive effects of low-risk etiologic factors involved in the formation of peri-implantitis might reach inflammation and bone resorption at 10 years that may indicate implant removal.

In the examined population, fixed prostheses anchored at the same time on implant and natural teeth were the most common type of prostheses anchored removed implants. Along with designing an implantsupported prosthesis, the biomechanical properties of natural teeth, implants, and anchored dentures must be taken into account. Natural tooth provides a flexible connection with bone by periodontal ligaments, so fixed prosthesis on the tooth may have micromovements. ${ }^{25}$ The connection among implants and bone is rigid and ankylotic, as there are no periodontal ligaments between them. In the case of implant-supported prosthesis, no or only very slight micromovements are observed. Micromovements generated by natural tooth are also transmitted to implants, assuming that the two types of anchoring are connected. Micromovement forces can weaken implantbone relationship over time, helping penetration and adhesion of pathogens around the implant, thereby promoting the formation of peri-implantitis. ${ }^{37,38}$ The second most common type of prosthesis was fixed prosthesis 


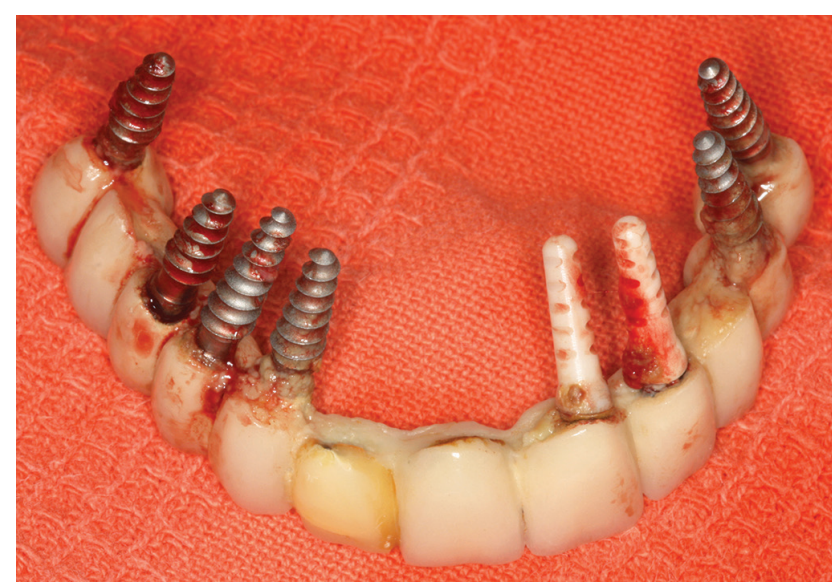

Fig. 5: Removed implant with prosthesis by peri-implantitis (from Dr Béla Czinkóczky's cases)

anchored on implant. In many cases, the inappropriate design of prosthesis led to increased accumulation of dental plaque, which can provoke the formation of periimplant inflammation, thus contributing to the loss of the implant ${ }^{14,39}$ (Fig. 5).

In nearly three-quarters of the removed implants, peri-implantitis was observed. High prevalence rates point to the fact that peri-implantal inflammation is one of the most important factors for losing implants (Fig. 6). The presence of certain etiologic factors contributes to the development of peri-implantitis, such as insufficient oral hygiene, smoking, inadequate loading of the implant, various systemic diseases, and inadequately designed or completed dentures. ${ }^{16}$ Periodontitis could also promote the development of peri-implantitis. In patients suffering from periodontitis, the incidence of peri-implantitis is six times greater, due to the fact that the anaerobic bacterial flora around sore implants and periodontally affected tooth are largely identical. ${ }^{40,41}$ Horizontal bone resorption can be observed in $47.6 \%$ of patients who have been with tooth and implant removal in the last $3 \frac{1}{2}$ years in the Department of Community Dentistry. This confirms the assumption that there is a correlation between periodontal status and survival of implants; $15.2 \%$ of the removed implants were explanted due to inflammatory reactions previous to osseointegration. In these cases, the healing process might have been affected by traumatic surgical care, disturbed implant healing, dehiscence due to inadequate wound care, and inadequate oral hygiene. ${ }^{42}$

\section{CONCLUSION}

Based on our results, our conclusions were deducted:

- Avoid planning fixed prostheses anchored at the same time to tooth and implant, because biomechanical aspects of anchoring of natural tooth and implants behave differently in the bone.

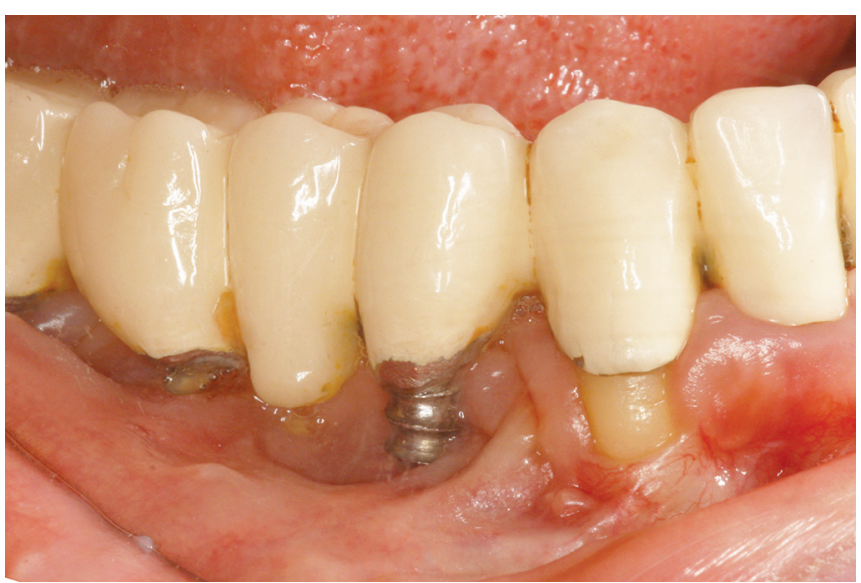

Fig. 6: Peri-implantitis

- In cases of implant-supported fixed prostheses, the aim is to give properly cleanable prostheses and to help create the patient's correct oral hygiene habits.

- Prevention of peri-implantitis is a key factor in the success of implants. In each case, we should try to minimize the presence of factors promoting the development of the disease. Sufficient oral hygiene is essential for the prevention of inflammation, the chances of which can be reduced by frequent controls.

- Patients with periodontitis should be cured of inflammation before implantation. Thus, we can reduce the chance of periodontal anaerobic flora adhesion around the implant causing inflammation.

- An essential factor for osseointegration is inflammation-free healing. We can choose our best-controlled wound-healing technique for our patients, as we can best reduce the progression of inflammatory processes.

\section{REFERENCES}

1. Romeo E, Lops D, Margutti E, Ghisolfi M, Chiapasco M, Vogel G. Long-term survival and success of oral implants in the treatment of full and partial arches: a 7-year prospective study with the ITI dental implant system. Int J Oral Maxillofac Implants 2004 Mar-Apr;19(2):247-259.

2. Compton SM, Clark D, Chan S, Kuc I, Wubie BA, Levin L. Dental implants in the elderly population: a long-term followup. Int J Oral Maxillofac Implants 2017 Jan-Feb;32(1):164-170.

3. Divinyi, T. Orális implantológia. Budapest: Semmelweis Kiadó; 2007.

4. Grisar K, Sinha D, Schoenaers J, Dormaar T, Politis C. Retrospective analysis of dental implants placed between 2012 and 2014: indications, risk factors, and early survival. Int J Oral Maxillofac Implants 2017 May-Jun;32(3):649-654.

5. Bragger, U.; Heitz-Mayfield, LJ. ITI Treatment Guide: biological and hardware complications in implant dentistry. Vol. 8. Berlin: Quintessenz Verlags; 2015.

6. Machtei EE. What do we do after an implant fails? A review of treatment alternatives for failed implants. Int J Periodontics Restorative Dent 2013 Jul-Aug;33(4):e111-e119. 
7. Iványi, D.; Kivovics, P. A fogászati implantátumok eltávolításának lehetséges okai és módszerei. In: Magyar Fogorvos.Budapest: Semmelweis University; 2017. pp. 86-89.

8. Alhassani AA, AlGhamdi AS. Inferior alveolar nerve injury in implant dentistry: diagnosis, causes, prevention, and management. J Oral Implantol 2010 Jun;36(5):401-407.

9. Auyong TG, Le A. Dentoalveolar nerve injury. Oral Maxillofac Surg Clin North Am 2011 Aug;23(3):395-400.

10. Yoon WJ, Kim SG, Jeong MA, Oh JS, You JS. Prognosis and evaluation of tooth damage caused by implant fixtures. J Korean Assoc Oral Maxillofac Surg 2013 Jun;39(3):144-147.

11. Kahraman S, Bal BT, Asar NV, Turkyilmaz I, Tözüm TF. Clinical study on the insertion torque and wireless resonance frequency analysis in the assessment of torque capacity and stability of self-tapping dental implants. J Oral Rehabil 2009 Oct;36(10):755-761.

12. Javed F, Ahmed HB, Crespi R, Romanos GE. Role of primary stability for successful osseointegration of dental implants: factors of influence and evaluation. Interv Med Appl Sci 2013 Dec;5(4):162-167.

13. Worthington P, Bolender CL, Taylor TD. The Swedish system of osseointegrated implants: problems and complications encountered during a 4-year trial period. Int J Oral Maxillofac Implants 1987 Summer;2(2):77-84.

14. Mombelli A, van Oosten MA, Schurch E Jr, Land NP. The microbiota associated with successful or failing osseointegrated titanium implants. Oral Microbiol Immunol 1987 Dec;2(4):145-151.

15. Klinge B, Meyle J; Working Group 2. Peri-implant tissue destruction. The Third EAO Consensus Conference 2012. Clin Oral Implants Res 2012 Oct;23(Suppl 6):108-110.

16. Heitz-Mayfield L. Peri-implant diseases: diagnosis and risk indicators. J Clin Periodontol 2008 Sep;35(8 Suppl):292-304.

17. Heitz-Mayfield LJ, Needleman I, Salvi GE, Pjetursson BE. Consensus statements and clinical recommendations for prevention and management of biologic and technical implant complications. Int J Oral Maxillofac Implants 2014;29(Suppl):346-350.

18. Schwarz MS. Mechanical complications of dental implants. Clin Oral Implants Res 2000;11(Suppl 1):156-158.

19. Amin RA. Dr. Ramsey Amin's Page. 2010. Available from: http://www.burbankdentalimplants.com.

20. Yerit KC, Posch M, Seemann M, Hainich S, Dörtbudak O, Turhani D, Ozyuvaci H, Watzinger F, Ewers R. Implant survival in mandibles of irradiated oral cancer patients. Clin Oral Implants Res 2006 Jun;17(3):337-344.

21. Harrison JS, Stratemann S, Redding SW. Dental implants for patients who have had radiation treatment for head and neck cancer. Spec Care Dent 2003 Nov-Dec;23(6):223-229.

22. Albrektsson T, Chrcanovic B, Östman PO, Sennerby L. Initial and long-term crestal bone responses to modern dental implants. Periodontology 20002017 Feb;73(1):41-50.

23. Jimbo R, Albrektsson T. Long-term clinical success of minimally and moderately rough oral implants: a review of 71studies with 5 years or more of follow-up. Implant Dent 2015 Feb;24(1):62-69.
24. Straumann ${ }^{\odot}$ Implants. Guidance for implant removal. 2012.

25. Skalak R. Biomedical considerations in osseointegrated prostheses. J Prosthet Dent 1983 Jun;49(6):843-848.

26. Stajčić Z, Stojčev Stajčić LJ, Kalanović M, Đinić A, Divekar N, Rodić M. Removal of dental implants: review of five different techniques. Int J Oral Maxillofac Surg 2016 May;45(5):641-648.

27. Yaman Z, Suer BT. Piezoelectric surgery in oral and maxillofacial surgery. Ann Oral Maxillofac Surg 2013 Feb;1(1):5.

28. Beaudoin, M. Oral health. 2012. Available from: http://www. oralhealthgroup.com/features/removing-implants-with-atwist/.

29. György J, László B, Gábor W. A diabetes mellitus kórismézése, a cukorbetegek kezelése és gondozása a felnőttkorban. A magyar diabetes társaság szakmai irányelve. Diabetologia Hungarica 2014;14(Suppl):1-48.

30. György S. Kardiovaszkuláris betegségek morbiditási viszonyai Magyarországon. 2002.

31. Anna T. A daganatos betegségek előfordulása, a hazai és a nemzetközi helyzet ismertetése. Magyar Tudomány 2011; 11:1333-1345

32. Madléna M, Hermann P, Jáhn M, Fejérdy P. Caries prevalence and tooth loss in Hungarian adult population: results of a national survey. BMC Public Health 2008 Oct;8:364.

33. Tibor F, Pal F, Endre S. Magyarország felnőtt lakossága fogazatának értékelése a fogpótlás szempontjából. Fogorvosi Szemle 1998;91(12):383-389.

34. Çakur B, Yıldız M, Dane ,Zorba YO. The effect of right or left handedness on caries experience and oral hygiene. J Neurosci Rural Pract 2011 Jan-Jun;2(1):40-42.

35. Chanavaz M. Anatomy and histophysiology of the periosteum: quantification of the periosteal blood supply to the adjacent bone with $85 \mathrm{Sr}$ and gamma spectrometry. J Oral Implantol 1995;21(3):214-219.

36. Tolstunov L. Implant zones of the jaws: implant location and related success rate. J Oral Implantol 2007;33(4):211-220.

37. Winter W, Klein D, Karl M. Micromotion of dental implants: basic mechanical considerations. J Med Eng 2013 Sep;2013:265412.

38. Charalampakis G, Leonhardt $\AA$, Rabe P, Dahlén G. Clinical and microbiological characteristics of peri-implantitis cases: a retrospective multicentre study. Clin Oral Implants Res 2012 Sep;23(9):1045-1054.

39. Ericsson I, Persson LG, Berglundh T, Marinello CP, Lindhe J, Klinge B. Different types of inflammatory reactions in peri-implant soft tissues. J Clin Periodontol 1995 Apr;22(3): 255-261.

40. Zitzmann N, Walter C, Berglundh T. Ätiologie, diagnostik und therapie der periimplantitis-eine übersicht. Deutsche Zahnärztliche Zeitschrift 2006 Jan;61:642-649.

41. Rams TE, Degener JE, van Winkelhoff AJ. Antibiotic resistance in human peri-implantitis microbiota. Clin Oral Implants Res 2013 Jan;25(1):82-90.

42. Salonen MA, Oikarinen K, Virtanen K, Pernu H. Failures in the osseointegration of endosseous implants. Int J Oral Maxillofac Implants 1993;8(1):92-97. 